\title{
ACCURACY OF AIR TEMPERATURE FORECASTS AND ITS USE FOR PREDICTION OF THE REFERENCE EVAPOTRANSPIRATION
}

\author{
ACURÁCIA DAS PREVISÕES DA TEMPERATURA DO AR E USO NA ESTIMATIVA \\ DA EVAPOTRANSPIRAÇÃO DE REFERENNCIA
}

\section{Claudio Ricardo da SILVA ${ }^{1}$; Lucas Andrade BARBOSA ${ }^{2}$; Rafael Resende FINZI ${ }^{2}$; Bruno Teixeira RIBEIRO ${ }^{3}$; Nildo da Silva DIAS ${ }^{4}$}

1. Professor, Doutor, Universidade Federal de Uberlândia - UFU, Instituto de Ciências Agrárias - ICIAG, Uberlândia, MG, Brasil. claudio.ricardo@ufu.br; 2. Mestrando em Agronomia, Programa de Pós-Graduação em Agronomia - UFU, Uberlândia, MG, Brasil; 3. Professor, Doutor, Universidade Federal de Lavras - UFLA, Departamento de Ciência do Solo - DCS, Lavras, MG. Brasil; 4. Prof. Doutor, Universidade Federal Rural do Semi-Árido - UFERSA, Departamento de Ciências Agronômicas e Florestais - DCAF, Mossoró, RN, Brasil

ABSTRACT: The objective of this study was to verify the quality of the short-term forecasts made by some web sites, as well as the potential of its use in estimating reference evapotranspiration (ETo). For the period 2012-2013, every 4-days, the maximum (Tmax) and minimum (Tmin) air temperature forecasts for horizons of 24, 48, 72 and 96 hours provided by public sites for Uberlandia-MG were collected and used for calculating the reference evapotranspiration (ETo) by the Hargreaves-Samani (HS) calibrated equation. The sites www.accuweather.com (WEATHER); www.cemig.com.br (CEMIG); jornaldotempo.uol.com.br; (JORNAL) and www.climatempo.com.br (CLIMA) were evaluated. For the same period, the meteorological data were taken at the National Institute of Meteorology (www.inmet.gov.br). The performance of the Tmax and Tmin forecasts as well as the ETo estimates were made by regression analysis, the mean bias error (MBE), root mean square error (RMSE) and t-test. For all sites, there was a better performance in the prediction of Tmin when compared to Tmax, especially by a reduction in errors (MBE and RMSE) and an increase in coefficients $b$ and $\mathrm{R}^{2}$. For ETo, the site CLIMA had lowest MBE and RMSE $\left(0.9 \mathrm{~mm} \mathrm{~d}^{-1}\right)$ following by the WEATHER and JORNAL. On the other hand, the site CEMIG presented higher values for MBE $\left(-1.3 \mathrm{~mm} \mathrm{~d}^{-1}\right)$ and RMSE $\left(1.6 \mathrm{~mm} \mathrm{~d}^{-1}\right)$. There was no worsening with an increase of the forecast horizon in these indices, except for $\mathrm{R}^{2}$ values. The site CLIMA was the only one that did not differ significantly from the ETo values observed. The results of diagnostic verification procedures indicate the potential use of air temperature forecasts in irrigation management.

KEYWORDS: ETo. Hargreaves. Irrigation management. Weather forecast.

\section{INTRODUCTION}

The purpose of a weather forecast should be to help people organize their daily tasks that are influenced by weather conditions. However, it is in agriculture that this information becomes more valuable because growth and development of plants in a natural environment are the results of the interactions of two major regimes: the genetic potential of individual plants and the external environment (REDDY et al., 1997).

For farmers, the use of an accurate public weather forecast can provide support in tactical decisions that will be taken to guarantee ideal crop development, especially irrigation management due to its dependence on the weather.

The choice of whether or not to initiate irrigation could be improved by taking advantage of short-term weather forecast information, if it is available (GOWING; EJIEJI, 2001). Also, it is possible to determine one of the most important parameters for rational irrigation water management, the reference being evapotranspiration (ETo) (PEREIRA, et al., 2014, YANG et al., 2016). The ETo expresses the evaporating power of the atmosphere at a specific location and time of the year and does not consider the crop characteristics and soil factors (ALLEN et al., 1998).

The use of weather the forecast for estimating ETo has been analyzed by some recent researches, especially in China (XU et al., 2012, LUO et al., 2014, YANG, 2016). However, it is very important to be evaluated it in other locations and climates, since errors are inherent in the forecasting process (MACHADO et al., 2010) and therefore, forecast verification is essential for monitoring accuracy, understanding errors, and making improvements in forecasting systems (EBERT et al., 2013). 
Thus, the aim of this study was: a) to verify the accuracy level of public maximum and minimum air temperature forecast for horizons of 24, 48, 72 and 96 hours for Uberlandia, Minas Gerais, Brazil and, b) to evaluate its use for estimating the reference evapotranspiration (ETo).

\section{MATERIAL AND METHODS}

From April 2012 to April 2013, daily air maximum (Tmax) and minimum (Tmin) temperature forecasts for Uberlandia, Minas Gerais $\left(18^{\circ} 55^{\prime} \mathrm{S}, 48^{\circ} 16^{\prime} \mathrm{W}, 863 \mathrm{~m}\right)$ were collected at each four days in 24, 48, 72 and 98 hours in advance (horizons) at the following public sites: 1) www.accuweather.com; (2) www.cemig.com.br; (3) jornaldotempo.uol.com.br;

www.climatempo.com.br. These sites were namely: WEATHER, CEMIG, JORNAL and CLIMA, respectively. They were chosen because they are commonly used by the city media and by the ease of accessing data on the Internet or smartphones.

For the same period, the meteorological data were collected by an automatic weather station managed by the National Institute of Meteorology (INMET - www.inmet.gov.br). As the weather data were reported on an hourly basis, it was necessary to integrate the values into a daily format, to standardize same with the forecast data provided by the sites.

The estimation of the reference evapotranspiration $\left(\mathrm{mm} \mathrm{d}^{-1}\right)$ from the maximum and minimum air temperature (ETo) was obtained by the equation proposed by HARGREAVES \& SAMANI (1985). The equation is defined as (Equation 1):

$$
\mathrm{ET0}=\mathrm{a} \times \operatorname{Ra} \times\left[\left(\frac{\operatorname{Tmax}_{\mathrm{m}}+\mathrm{Tmin}}{2}\right)+17,8\right] \times(\operatorname{Tmax}-\mathrm{Tmin})^{3}
$$

Where $a, b$ are adjustment coefficients, Tmax and Tmin are the maximum and minimum air temperature $\left({ }^{\circ} \mathrm{C}\right), \mathrm{Ra}$ is the daily extraterrestrial solar radiation $\left(\mathrm{mm} \mathrm{d}^{-1}\right)$ which was calculated as proposed by Allen (1998).

Although the ETo-HS equation has been used and tested in different climatic conditions, local calibrations can improve its accuracy (XU et al., 2012; SENTELHAS et al., 2010; LUO et al., 2014). Thus, the coefficients of the equation were optimized from ETo values calculated by the Penman-Monteith equation (ETo-PM), which is considered as a universal standard for estimating ETo (ALLEN et al., 1998). The observed meteorological data from 2009-2010 and 2010-
2012 were used to locally calibrate and validate the ETo-HS equation, respectively.

The observed and estimated values of Tmax, Tmin and ETo were submitted to the following statistics treatments: i) regression analyzes between observed and estimated values, with the linear coefficient through the origin and the slope used as a measure of accuracy while coefficient of determination $\left(\mathrm{R}^{2}\right)$ as a measure of precision; ii) mean bias error (MBE) and root mean square error (RMSE) calculated as (Equation 2 and $3)$ :

MBE $=\frac{1}{n} \sum_{i=1}^{n}\left(E_{i}-O_{i}\right)$
RMSE $=\left[\frac{1}{n} \sum_{i=1}^{n}\left(E_{i}-O_{i}\right)^{2}\right]^{0,5}$

Where Ei is the ith estimated and Oi is the $\mathrm{i}$ th observed values and $\mathrm{n}$ is the number of pairs.

As suggested by Jacovides and Kontoyianni (1995), the t-statistic was used as a supplement for the MBE and RMSE errors, by indicating whether estimates values were statistically significant at 0,005 level of significance. The t-statistics is defined through MBE and RMSE errors as (Equation 4):

$$
\mathrm{t}=\left[\frac{(\mathrm{n}-1) \mathrm{MBE}^{2}}{\mathrm{RMSE}^{2}-\mathrm{MBE}^{2}}\right] 0,5
$$

\section{RESULTS AND DISCUSSION}

\section{The air maximum and minimum temperature forecasts}

The statistics results for air maximum (Tmax) and minimum temperature (Tmin) forecasts for each site and prediction horizons $(24,48,72$ and 96h) are in Table 1. Regarding Tmax, except for the JORNAL, there was a tendency of underestimation, with the MBE ranging from $-0.4^{\circ} \mathrm{C}$ (CLIMA) to $3.2^{\circ} \mathrm{C}$ (CEMIG). The RMSE was uniform between sites and forecast horizons $\left(2.3^{\circ} \mathrm{C}\right)$ but CEMIG had higher values, with $3.9^{\circ} \mathrm{C}$ on average. The values were close to those obtained by Brooks et al. (1997) in Oklahoma and by Xu et al. (2012) and Luo et al. (2014) in many locations in China. The coefficient b was higher than 0.8 in most of sites, showing a high correlation between estimated and observed Tmax values. However, the $\mathrm{R}^{2}$ was lower, especially as the forecast horizon increased. When analyzing the $\mathrm{t}$ - 
test, it was verified that only the Tmax forecasts

significantly $(\mathrm{p}<0.05)$ from the observed values.

carried out by the JORNAL did not differ

Table 1. Mean bias error (MBE), root mean square error (RMSE), coefficient of determination ( $\left.\mathrm{R}^{2}\right)$, linear regression coefficient (b) and value of the t-test for the predicted temperatures by the sites in forecast horizons of $24,48,72$ and 96 hours.

\begin{tabular}{|c|c|c|c|c|c|c|c|c|c|c|c|}
\hline \multirow{2}{*}{ Sites } & \multirow[t]{2}{*}{ Horiz. } & \multicolumn{5}{|c|}{ Maximum air temperature $\left({ }^{\circ} \mathrm{C}\right)$} & \multicolumn{5}{|c|}{ Minimum air temperature $\left({ }^{\circ} \mathrm{C}\right)$} \\
\hline & & MBE & RMSE & $\mathrm{R}^{2}$ & $\mathrm{~b}$ & $\mathrm{t}$ & $\mathrm{MBE}$ & RMSE & $\mathrm{R}^{2}$ & $\mathrm{~b}$ & $\mathrm{t}$ \\
\hline \multirow{5}{*}{ 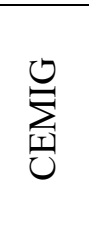 } & $24 \mathrm{~h}$ & -3.1 & 3.7 & 0.55 & 0.88 & 26.1 & -0.4 & 1.6 & 0.66 & 0.97 & 4.3 \\
\hline & $48 \mathrm{~h}$ & -3.2 & 3.7 & 0.61 & 0.88 & & -0.4 & 1.9 & 0.55 & 0.97 & \\
\hline & $72 \mathrm{~h}$ & -3.2 & 4.1 & 0.35 & 0.88 & & -0.6 & 2.0 & 0.54 & 0.96 & \\
\hline & $96 \mathrm{~h}$ & -3.3 & 4.2 & 0.25 & 0.88 & & -0.3 & 2.0 & 0.49 & 0.97 & \\
\hline & Mean & -3.2 & 3.9 & 0.44 & 0.88 & & -0.4 & 1.9 & 0.56 & 0.96 & \\
\hline \multirow{5}{*}{ 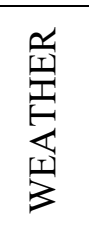 } & $24 \mathrm{~h}$ & -1.2 & 2.1 & 0.54 & 0.95 & 11.7 & $\begin{array}{c}-1.8 \\
\end{array}$ & 2.2 & 0.73 & 0.90 & 22.8 \\
\hline & $48 \mathrm{~h}$ & -1.3 & 2.3 & 0.46 & 0.95 & & -1.8 & 2.4 & 0.68 & 0.89 & \\
\hline & $72 \mathrm{~h}$ & -1.3 & 2.4 & 0.37 & 0.95 & & -1.9 & 2.4 & 0.61 & 0.89 & \\
\hline & $96 \mathrm{~h}$ & -1.3 & 2.5 & 0.23 & 0.95 & & -1.7 & 2.4 & 0.54 & 0.90 & \\
\hline & Mean & -1.27 & 2.4 & 0.40 & 0.95 & & -1.8 & 2.4 & 0.64 & 0.89 & \\
\hline \multirow{5}{*}{$\begin{array}{l}\text { 岕 } \\
\text { Zֶ, } \\
\stackrel{\sigma}{0}\end{array}$} & $24 \mathrm{~h}$ & 0.1 & 2.4 & 0.45 & 1.00 & -1.1 & -1.1 & 1.9 & 0.67 & 0.94 & 11.7 \\
\hline & $48 \mathrm{~h}$ & 0.2 & 2.2 & 0.55 & 1.00 & & -1.2 & 2.1 & 0.64 & 0.93 & \\
\hline & $72 \mathrm{~h}$ & 0.1 & 2.4 & 0.38 & 1.00 & & -1.1 & 2.2 & 0.60 & 0.93 & \\
\hline & $96 \mathrm{~h}$ & 0.2 & 2.8 & 0.27 & 1.00 & & -0.1 & 2.2 & 0.51 & 0.94 & \\
\hline & Mean & 0.14 & 2.5 & 0.41 & 1.00 & & -1.1 & 2.1 & 0.60 & 0.93 & \\
\hline \multirow{5}{*}{$\underset{\Xi}{\leftrightarrows}$} & $24 \mathrm{~h}$ & -0.4 & 1.7 & 0.63 & 0.98 & 3.7 & -0.7 & 1.7 & 0.70 & 0.95 & 8.5 \\
\hline & $48 \mathrm{~h}$ & -0.4 & 2.2 & 0.36 & 0.98 & & -0.8 & 1.9 & 0.66 & 0.95 & \\
\hline & $72 \mathrm{~h}$ & -0.5 & 2.1 & 0.25 & 0.97 & & -0.9 & 1.9 & 0.61 & 0.95 & \\
\hline & $96 \mathrm{~h}$ & -0.3 & 2.1 & 0.24 & 0.98 & & -0.7 & 2.3 & 0.43 & 0.95 & \\
\hline & Mean & -0.4 & 2.0 & $\mathbf{0 . 3 7}$ & 0.98 & & -0.8 & 1.9 & 0.60 & 0.95 & \\
\hline
\end{tabular}

In Table 1, it should be noted that for all sites there was a better performance in the prediction of Tmin when compared to Tmax, especially by reduction in errors (MBE and RMSE) and an increase in coefficients $b$ and $R^{2}$. This improvement can be explained by lower wind speeds and a more stable condition of the atmosphere during the night period (NICHOL, 2005). Similar results were also verified by Brooks et al. (1997) and Luo et al. (2014), although, Ballesteros et al. (2016) verified superior performance for Tmax in relation to Tmin. In general, the CEMIG address presented the best results, although it differed significantly from the observed Tmin values.

\section{The evaluation of ETo}

The statistics results for ETo calculated using maximum and minimum air temperature provided by sites are shown in Table 2 . The site CLIMA had lowest MBE and RMSE $\left(0.9 \mathrm{~mm} \mathrm{~d}^{-1}\right)$ following by sites WEATHER and JORNAL. On the other hand, the site CEMIG presented higher values of MBE $\left(-1.3 \mathrm{~mm} \mathrm{~d}^{-1}\right)$ and RMSE $\left(1.6 \mathrm{~mm} \mathrm{~d}^{-}\right.$ $\left.{ }^{1}\right)$. There was no worsening with increasing of the forecast horizon in these indices, except by $\mathrm{R}^{2}$ values, with maximum values for $24 \mathrm{~h}$ and worst for 96h hours in advance. The site CLIMA was the only one that did not differ significantly from the ETo values observed.

When comparing the ETo results with the performance analyzes for Tmax and Tmin forecasts, it is observed that the CLIMA had no great forecast performance as did the JORNAL and the CEMIG for Tmax and Tmin, respectively. However, it had the same underestimation tendency for Tmax and Tmin, with MBE values less than $1.0^{\circ} \mathrm{C}$. The site WEATHER had the same underestimation tendency, however MBE was greater than CLIMA. As ETo estimated by Hargreaves-Samani uses the temperature range $(\Delta \mathrm{T}=\mathrm{Tmax}-\mathrm{Tmin})$ as the main variable, thus errors in Tmax and Tmin temperature are combined into $\Delta \mathrm{T}$ error and, consequently, in the estimation of ETo. For example, if a forecast made by a site underestimates $2^{\circ} \mathrm{C}$ both Tmax and $\mathrm{Tmin}$, the error in $\Delta \mathrm{T}$ will be null, since the errors will be canceled. On the other hand, if the forecast 
had an opposite tendency for Tmax and Tmin, the $\Delta \mathrm{T}$ error would be $4^{\circ} \mathrm{C}$.

In China, Xu et al. (2012) analyzing the sensitivity of eighteen combinations of errors in Tmax and Tmin on the accuracy of ETo, found that errors in the daily ETo increased with $\Delta \mathrm{T}$ errors and the RMSE ranges from $0.827\left(\mathrm{Tmax}-1{ }^{\circ} \mathrm{C}\right.$, Tmin $1^{\circ} \mathrm{C}$ ) to $1.057 \mathrm{~mm} \mathrm{~d}^{-1}\left(\operatorname{Tmax}+2^{\circ} \mathrm{C}\right.$, Tmin $\left.-2^{\circ} \mathrm{C}\right)$. The authors also recommended that it is important to ensure a $\Delta \mathrm{T}$ error of less than $2^{\circ} \mathrm{C}$ for perfect estimation of ETo.

Table 2. Mean bias error (MBE), root mean square error (RMSE), coefficient of determination $\left(\mathrm{R}^{2}\right)$, slope of regression (b) and t-test calculated between the values of the reference evapotranspiration (ETo) obtained with maximum and minimum temperature data observed and predicted by sites. Uberlandia, MG.

\begin{tabular}{|c|c|c|c|c|c|c|}
\hline \multirow{2}{*}{ Sites } & \multirow[t]{2}{*}{ Horizon. } & \multicolumn{5}{|c|}{$\operatorname{ETo}\left(\mathrm{mm} \mathrm{d}^{-1}\right)$} \\
\hline & & MBE & RMSE & $\mathbf{R}^{2}$ & b & $\mathrm{t}$ \\
\hline \multirow{5}{*}{ CEMIG } & 24 & -1.1 & 1.4 & 0.42 & 0.68 & 22.4 \\
\hline & 48 & -1.2 & 1.5 & 0.41 & 0.65 & \\
\hline & 72 & -1.7 & 2.0 & 0.21 & 0.57 & \\
\hline & 96 & -1.2 & 1.7 & 0.15 & 0.63 & \\
\hline & Mean & -1.3 & 1.6 & 0.29 & 0.63 & \\
\hline \multirow{5}{*}{ WEATHER } & 24 & 0.0 & 0.7 & 0.53 & 0.99 & 2.9 \\
\hline & 48 & 0.0 & 0.9 & 0.32 & 0.98 & \\
\hline & 72 & -0.5 & 1.1 & 0.31 & 0.84 & \\
\hline & 96 & -0.1 & 0.9 & 0.05 & 0.93 & \\
\hline & Mean & -0.2 & 0.9 & 0.30 & 0.93 & \\
\hline \multirow{5}{*}{ JORNAL } & 24 & 0.4 & 1.2 & 0.42 & 1.09 & -3.4 \\
\hline & 48 & 0.5 & 1.2 & 0.51 & 1.12 & \\
\hline & 72 & -0.2 & 1.2 & 0.32 & 0.93 & \\
\hline & 96 & 0.3 & 1.4 & 0.05 & 1.04 & \\
\hline & Mean & 0.3 & 1.3 & 0.32 & 1.04 & \\
\hline \multirow{5}{*}{ CLIMA } & 24 & 0.1 & 0.7 & 0.56 & 1.00 & 1.7 \\
\hline & 48 & 0.1 & 0.9 & 0.32 & 0.99 & \\
\hline & 72 & -0.5 & 0.9 & 0.49 & 0.86 & \\
\hline & 96 & 0.0 & 0.9 & 0.32 & 0.98 & \\
\hline & Mean & 0.0 & 0.9 & 0.42 & 0.95 & \\
\hline
\end{tabular}

\section{CONCLUSIONS}

For all sites, there was a better performance in the prediction of Tmin when compared to Tmax, especially by a reduction in errors (MBE and RMSE) and an increase in coefficients $b$ and $R^{2}$. The site JORNAL was the only one that did not differ from the observed Tmax values, with mean MBE and RMSE of 0.14 and $2.5^{\circ} \mathrm{C}$, respectively.
For Tmin, all sites differed from observed values, despite this, the mean errors in Tmin forecasts were less than the errors in Tmax forecasts for all sites.

The errors in Tmax and Tmin were combined in ETo. For this reason, although the site CLIMA did not show higher performance for Tmax and Tmin, it was the only one that did not differ from the observed ETo values, with MBE null and RMSE of $0.9 \mathrm{~mm} \mathrm{~d}^{-1}$.

RESUMO: O objetivo deste trabalho foi verificar a qualidade das previsões de curto prazo feitas por alguns endereços eletrônicos da internet, bem como a potencialidade de seu uso na estimativa da evapotranspiração de referência (ETo). No período de 2012 a 2013, a cada quatro dias, foram coletadas as previsões de 24,48,72 e 96 de horizonte, da temperatura máxima (Tmax) e mínima (Tmin) do ar de quatro endereços eletrônicos para a cidade de Uberlândia, MG. Os dados previstos de temperatura, foram utilizados na equação calibrada do modelo de Hargreaves-Samani (HS) para a obtenção da estimativa da ETo. Os endereços avaliados foram: www.accuweather.com (WEATHER); www.cemig.com.br (CEMIG); jornaldotempo.uol.com.br; (JORNAL) e www.climatempo.com.br (CLIMA). No mesmo período, dados 
meteorológicos da cidade foram obtidos junto ao Instituto Nacional de Meteorologia (www.inmet.gov.br). A performance das previsões da temperatura e estimativas de ETo foram feitas por meio da análise de regressão, erro médio (EM), raiz quadrada do quadrado médio do erro (RQME) e pelo teste-t. Para todos os endereços, houve uma melhor performance na previsão da Tmin em relação a Tmax, especialmente pela redução dos erros (ME e RQME) e aumento nos coeficientes $b$ e $\mathrm{R}^{2}$. Para ETo, o endereço CLIMA obteve os menores valores de EM e RQME $\left(0,9 \mathrm{~mm} \mathrm{~d}^{-1}\right)$ seguido do endereço WEATHER e JORNAL. Por outro lado, o endereço CEMIG apresentou os maiores valores para EM $\left(-1,3 \mathrm{~mm} \mathrm{~d}^{-1}\right)$ e RQME $\left(1,6 \mathrm{~mm} \mathrm{~d}^{-1}\right)$. Não houve piora na estimativa com aumento do horizonte de previsão nesses índices, exceto para $\mathrm{R}^{2}$. $\mathrm{O}$ endereço CLIMA foi o único que não diferiu significativamente dos valores de ETo observados. Os resultados de verificação indicam potencial uso das previsões para o manejo da irrigação.

PALAVRAS-CHAVES: ETo. Hargreaves. Manejo de irrigação. Previsão do tempo.

\section{REFERENCES}

ALLEN, R.G.; PEREIRA, L. S.; RAES, D.; SMITH, M. Crop evapotranspiration: guidelines for computing crop water requirements. FAO Irrigation and Drainage Paper, v.56, p.300, 1998. Disponível em: < http://www.fao.org/docrep/x0490e/x0490e00.htm>. Acesso em :24 de fev. 2016.

BALLESTEROS, R.; ORTEGA, J.F.; MORENO, M.A. New software for reference evapotranspiration forecasting. Journal of Aried Environments, v.124, p.128-141, 2016.

https://doi.org/10.1016/j.jaridenv.2015.08.006

BROOKS, H.E.; WITT, A.; EITS, M.D. Verification of public weather forecasts available via the media. Bulletin of the American Meteorological Society, v.78, p.2167-2177, 1997. https://doi.org/10.1175/15200477(1997)078<2167:VOPWFA>2.0.CO;2

EBERT, E.; WILSON, L.; WEIGEL, A.; MITTERMAIER, M.; NURMI, P.; GILL, P.; GOBER, M.; JOSLYN, S.; BROWN, B.; FOWLER, T.; WATKINS, A. Progress and challenges in forecast verification.

Meteorological applications, v.20, p.130-139, 2013. https://doi.org/10.1002/met.1392

GOWING, J.W.; EJIEJI, C.J. Real-time scheduling of supplemental irrigation for potatoes using a decision model and short-term weather forecasts. Agricultural Water Management, v.47, n.2, p.137-153, 2001. https://doi.org/10.1016/S0378-3774(00)00101-3

JACOVIDES, C.P.; KONTOYIANNIS, H. Statistical procedures for the evaluation of evapotranspiration computing models. Agricultural Water Management, v.27, p.365-371, 1995. https://doi.org/10.1016/03783774(95)01152-9

LUO, Y.; CHANG, X.; PENG, S.; KHAN, S.; WANG, W.; ZHENG, Q.; CALI, X. Short-term forecasting daily reference evapotranspiration using the Hargreaves-Samani model and temperature forecasts. Agricultural Water Management, v.136, p.42-51, 2014. https://doi.org/10.1016/j.agwat.2014.01.006

MACHADO, L.H.R.; MENDONÇA, A.M.; MENDONÇA, R.W.B.; BONATTI, J.P. Impacto da utilização de previsões "defasadas" no sistema de previsão de tempo por conjunto do CPTEC/INPE. Revista Brasileira de Meteorologia, v.25, n.1, p.54-69, 2010. https://doi.org/10.1590/S0102-77862010000100006

NICHOL, J. Remote sensing of urban heat islands by day and night. Photogrammetric Engineering \& remote sensing, v.71, n.5, p.613-621, 2005. https://doi.org/10.1590/S0102-77862010000100006

PEREIRA, K.C.; WESTERN, A.W.; NAWARATHNA, B.; GEORGE, B. Forecasting daily reference evapotranspiration for Australia using numerical weather prediction outputs. Agricultural and Forest Meteorology, v.194, p. 50-63, 2014. https://doi.org/10.1016/j.agrformet.2014.03.014 
REDDY, K.R.; HODGES, H.F.; MCKINION, J.F. Crop modeling applications: a Cotton example. In: SPARKS. D. L. Advances in Agronomy. 1. ed. San Diego: Academicy prass, 1997. cap. 6, p. 225-290. https://doi.org/10.1016/S0065-2113(08)60056-5

SENTELHAS, P.C.; GILLESPIE, T.J.; SANTOS, E.A. Evaluation of FAO Penman-Monteith and alternative methods for estimating reference evapotranspiration with missing data in Southern Ontario, Canada.

Agricultural Water Management, v.97, p.635-644, 2010. https://doi.org/10.1016/j.agwat.2009.12.001

YANG, Y.; CUI, Y.; LUO,Y.; LYU,X.; TRAORE,S.; KHAN,S.; WANG,W. Short-term forecasting of daily reference evapotranspiration using the Penman-Monteith model and public weather forecasts. Agricultural Water Management, v.177, p.329-339, 2016. https://doi.org/10.1016/j.agwat.2016.08.020

XU, J.Z.; PENG, S.Z.; YANG, S.H; LUO, Y.F.; WANG, Y.J. Predicting daily reference evapotranspiration in a humid region of china by the locally calibrated Hargreaves-Samani equation using weather forecast data. Journal of Agricultural Science and Technology, v.14, p.1331-1342, 2012. 